\title{
Book Review "Religion Explained? The Cognitive Science of Religion after Twenty-Five Years"
}

Hans Van Eyghen

VU Amsterdam,

The Netherlands

e-mail: h.m.r.a.van.eyghen@vu.nl

\begin{abstract}
:
I review the book "Religion Explained? The Cognitive Science of Religion after Twenty-Five Years." I discuss all the papers in the book and highlight some recurrent issues.

Keywords: Cognitive Science of Religion, psychology of religion, definition of religion, history of Science.
\end{abstract}

Religion Explained? The Cognitive Science of Religion after Twenty-Five Years, Edited by Luther H. Martin \& Donald Wiebe, Bloomsbury Academic 2017, 272 pp.

In the book "Religion Explained? The Cognitive Science of Religion after 25 years" some of the leading scholars in cognitive science of religion (CSR) reflect on the past, present and future of their discipline. Although the subdivisions suggest that past, present and future are discussed separately, most contributors share their reflections on all three. Contrary to what the title suggests, the book offers much more than historical reflection. All contributors present their (sometimes critical) take on the strengths and weaknesses of CSR

\section{Retrospectives}

The first part, titled 'Retrospectives,' has papers by the two fathers of CSR (E. Thomas Lawson and Robert McCauley). Lawson discusses how the body of knowledge delivered by CSR has grown over the years. He repeats his well-known criticism of other, more descriptive approaches to the study of religion and considers this a prerequisite for the growth of knowledge of religion. He highlights theories about the role of cognitive mechanisms, like agency detection, as important accomplishments in CSR. Lawson is critical about David Sloan Wilson's failure to take cognitive mechanisms into account. Another important accomplishment in Lawson's view is the successful application of Dan Sperber's epidemiology of beliefs to religious beliefs. Lawson concludes that by-product theories (CSR-theories that consider religious belief not as evolutionary adaptations in themselves but rather as by-products of adaptations) have yielded a far more interesting and broader picture of religion than competing adaptationist theories.

Robert McCauley's also reiterates the points of divergence of CSR and other approaches in religious studies. He defends his discipline by pointing to its many successes. In line with his work 
on explanatory pluralism, McCauley celebrates the diversity within CSR. He ends with a warning that CSR should not aim at offering complete explanations of religion. In science there is no such thing as a complete explanation.

Harvey Whitehouse begins his paper with a discussion that returns in many other papers of the volume, namely the lack of clarity about the explanandum of CSR. In his view the explanandum, i. e. religion, is not a natural kind and is not a single coherent phenomenon but a rather loose bundle of things. These things demand different theories and approaches. He claims that the single most important insight CSR has taught is the idea that religious belief is shaped and constrained by implicit, universal intuitions. Whitehouse goes on to discuss his own work on religious rituals and how he was influenced by Pascal Boyer's ideas.

Uffe Schjoedt and Armin Geertz' paper starts with a warning. While CSR has matured it still consists of a small group of scholars who need to stick together to stand up to dominant competition in religious studies. They offer a longer list of CSR's achievements consisting of religious epidemiology, animism, agency detection, ritual representation, counterintuitive ideas and modes of religiosity. They suggest that future research in CSR should be more multidisciplinary to gain recognition in the humanities.

\section{State of the Art}

The second part of the book starts with a paper by the grandfather of CSR, Stewart Guthrie. He returns to the problem of defining the explanandum of CSR. In his view, the lack of a clear definition for 'religion' is a real problem. Guthrie also notes another apparent problem for CSR. He distinguishes two lines of research. One states that religious belief is generated intuitively. A clear example is Guthrie's own theory of animism. A second states that religious belief is counterintuitive. Its main defender is Pascal Boyer. In Guthrie's view both conflict.

The paper by Pascal Boyer and Nicolas Baumard highlights a problem for CSR that returns in later papers. The problem is how CSR-theories about general human cognitive mechanisms and their outputs can shed light on, or can be reconciled with particular historical religious phenomena. They also note a tension between CSR-theories that focus on the unconscious cognitive processes leading to religious beliefs and theories that take explicit, consciously held religious beliefs at face value. They propose ways how the divide can be overcome. They also return to the problem of defining 'religion' and argue that the term is of little use for cognitive and social scientists.

The paper by Panayotis Pachis and Olympia Panagiotidou focuses on the divide between the general universal features of religion and the particular historical religious phenomena. They call for intensified collaboration between scholars of history of religions and cognitive scientists to overcome it.

Anders Klostergaard Petersen continues on the same problem. His case study is magic, a topic which CSR has yet to do a lot of explaining. He suggests that cognitive science is indispensable for a future study of historical instantiations of religion but that a lot of work remains to be done.

\section{CSR 2.0}

Leonardo Ambasciano continues on the problem of bridging cognitive science and study of historical religions. He argues that CSR-theories has often been misunderstood as downgrading the history of religions or as considering them mere providers of data to test theories on. He accuses some prominent CSR-theorists of falling in this trap. Ambasciano also accuses some CSR-theorists of biased selection of variables and control groups to confirm their hypotheses. He argues that future CSR should do better justice to historical, particular context that always shapes religion.

The paper by Michael Porubanova and John Shaver is perhaps the most focused in the volume. They return to Pascal Boyer's theory stating that religious concepts matter to people because they are minimally counterintuitive. They argue that the theory needs to incorporate a role 
for emotions. They conclude from an experiment that subjects are more likely to remember (minimally counterintuitive) concepts in context of high emotional arousal.

The most critical piece in the volume is the paper by Benson Saler and Charles Ziegler. They return to the problem of defining CSR's explanandum 'religion' again. They also survey the criticisms of Ara Norenzayan's Big Gods Theory. The theory states that belief in moralizing gods became salient during the axial age when people started living in large-scale societies. They accuse Norenzayan of 'physics envy,' a tendency to portray theories as resembling theories in exact sciences.

Jesper Sorensen proposes a solution to the problem of bridging the gap between general cognitive theories of religious belief and particular historical religious phenomena. He argues that particular historical religious traditions should be considered as ways how humans modify their particular ecological niche with the tools furnishes by their general cognitive systems. He claims that this is a fruitful approach to overcome the gap.

\section{Looking Forward}

Richard Sosis is the first to answer the title-question of the book 'Has religion been explained?'. His answer is: no, but we are getting there. His paper gives advice to CSR-scholars on how they can succeed in explaining religion. He compares CSR to two other related disciplines, behavioral ecology and evolutionary psychology. He warns against following a path like behavioral ecology. Behavioral ecology saw a wide proliferation of societies and journals but no sufficient quality increase. Evolutionary psychology, by contrast, focused in producing qualitative research. As a result evolutionary psychology as a discipline is in much better shape than behavioral ecology. Unsurprisingly, Sosis sees evolutionary psychology as a good example for CSR to follow.

Justin Lane's paper mainly discusses the deep history of CSR. He traces its roots all the way back to late $19^{\text {th }}$ century theories about memory and perception (he calls it the prehistory of CSR). He also points to mid- $20^{\text {th }}$ century theories about language as influential for CSR. Like many of his predecessors, Lane discusses the problem of CSR's explanandum.

Steven Hrotic also discusses the deep history of CSR, mainly its predecessors in Victorian theories of evolutionism and cognitive anthropology. He concludes that there remains a lot of work to be done in CSR and highlights the importance of interdisciplinary work.

The final paper by Justin Barrett distinguishes a number of core commitments of CSR. One commitment is that CSR aims to explain cultural expressions that are commonly regarded as religious. By pointing to this commitment, Barrett proposes a solution to the problem of defining CSR's explanandum, namely by relying on a common sense understanding of the term. Other core commitments according to Barrett are methodological naturalism, interdisciplinarity and a focus on cognition. He also addresses the problem of bridging the gap between general theories and historical, cultural instantiations of religion. He sees it mainly as a problem of how to combine individual features of importance for religion and group-features.

\section{Conclusion}

While the quality of papers varies (which is almost inevitable in edited volumes) the book offers an indispensable discussion of the current state of CSR. Most of the papers presuppose too much information for the book to serve as an introduction to the field. For people who are familiar with CSR, the book presents new takes on key issues and problems in the field.

One point of criticism I want to put focus on is the almost conspicuous absence of philosophy. Philosophy not only helped shape the cognitive research program to which CSR is indebted, philosophers recently also offered insights how cognitive science can be improved or broadened. A major development is the stress on $4 \mathrm{E}$ cognition (cognition as embodied, embedded, enacted and extended). Only Robert McCauley mentions 4E cognition. Another way forward for CSR is engaging with these new insights. 